\title{
Functional cooperation of of IL-1 $\beta$ and RGS4 in the brachial plexus avulsion mediated brain reorganization
}

\author{
Jifeng Li, Hui Zhao*, Pengbo Luo, Yudong Gu
}

\begin{abstract}
Backgrounds: There is considerable evidence that central nervous system is continuously modulated by activity, behavior and skill acquisition. This study is to examine the reorganization in cortical and subcortical regions in response to brachial plexus avulsion.

Methods: Adult C57BL/6 mice were divided into four groups: control, 1, 3 and 6 month of brachial plexus avulsion. IL-1 $\beta$, IL-6 and RGS4 expression in cortex, brainstem and spinal cord were detected by BiostarM-140 s microarray and real-time PCR. RGS4 subcellular distribution and modulation were further analyzed by primary neuron culture and Western Blot.

Results: After 1, 3 and 6 months of brachial plexus avulsion, 49 ( 0 up, 49 down), 29 (17 up, 12 down), 13 (9 up, 4 down) genes in cerebral cortex, 40 (8 up, 32 down), 11 (7 up, 4 down), 137 (63 up, 74 down) in brainstem, 27 (14 up, 13 down), 33 (18 up, 15 down), 60 (29 up, 31 down) in spinal cord were identified. Among the regulated gene, IL-1 $\beta$ and IL-6 were sustainable enhanced in brain stem, while PKAC $\beta$ and RGS4 were up-regulated throughout cerebral cortex, brainstem and spinal cord in 3 and 6 month of nerve injury. Intriguingly, subcellular distribution of RGS4 in above three regions was dependent on the functional correlation of PKA and IL-1 $\beta$.

Conclusion: Data herein indicated that brachial plexus avulsion could efficiently initiate and perpetuate the brain reorganization. Network involved IL-1 $\beta$ and RGS4 signaling might implicate in the re-establish and strengthening of the local circuits at the cortical and subcortical levels.
\end{abstract}

\section{Backgrounds}

Neuroplasticity is the changing of neurons and the organization of their networks, which may happen through adding new cells or changing of the strength of the connections between neurons. For years it was believed that peripheral injuries could trigger a series of phenotypic changes $[1,2]$, such as neuronal reaction and chromatolysis, even functional plasticity and brain reorganization $[3,4]$. It was also reported that these alterations of neural substrates occurred with time dependent manner. Namely, rapid changes within minutes are likely due to unmasking of latent synapses, while the changes over a longer time are involve many mechanisms including long-term potentiation, axonal regeneration and sprouting $[5,6]$.

\footnotetext{
* Correspondence: mayzhao5375@yahoo.com

* Correspondence: mayzhao5375@yahoo.com
Lab of Hand function reconstruction, Huashan Hospital, Fudan University, Shanghai, China
}

(c) $2010 \mathrm{Li}$ et al; licensee BioMed Central Ltd. This is an Open Access article distributed under the terms of the Creative Commons Attribution License (http://creativecommons.org/licenses/by/2.0), which permits unrestricted use, distribution, and reproduction in any medium, provided the original work is properly cited.

Brachial plexus is formed by the union of the ventral primary rami of the spinal nerve, C5-C8 and T1 [7], which is a complex network of nerves which extends from the neck to the axilla and supplies motor, sensory, and sympathetic fibers to the upper extremity. Accordingly, brachial plexus avulsion usually results in a constant crushing and intermittent shooting pain, even the arm paralysis $[8,9]$. Recently, brain reorganization was reported to be induced by brachial plexus avulsion.

As well known, cells must integrate the signals that they receive from multiple pathways in order to respond efficiently to environmental cues. But, what happened with regard to brachial plexus avulsion? Up to now, many studies documented that peripheral nerve injury is tightly controlled by cytokines, G-protein coupled receptor pathways [10]. IL-1 $\beta$ and IL-6 in particular, they are not only implicated in the central inflammatory response in glial cells, but also in neuron actions, such 
as rapid changes in membrane ion currents, activation of neuron-specific CREB and the sphingomyelinase/ceremide pathways [11]. Importantly, these cytokines may eventually evolve into local circuitry and complex loops between cortical and subcortical locations [12].

For G-protein signaling, the emerging picture of G protein signaling (RGS) proteins reveals a highly diverse, multifunctional signaling network, which could permit fine-tuning of its interaction with cytokines [13-15]. This interaction presents the intriguing possibility to regulate signal capacity involving peripheral nerve injury. Accordingly, the present study was determined to examine brachial plexus avulsion induced specific gene expression, as well as the orchestrated G-protein signaling network in the CNS.

\section{Methods}

\section{Animal preparation}

All animal experiments were carried out in accordance with the guidelines and regulations for animal experimentation, NIH and Fudan University. Adult C57BL/6 mice weighing 18-20 g were used in the current experiment (Scientific Animal Center in Shanghai Medical College, Fudan University). The animals were housed in groups (5 per cage) in a controlled environment on a $12 \mathrm{~h}$ light-dark cycle, and allowed to acclimate for a minimum of 5 days before conducting experiments. Water and food were available at all times.

Brachial plexus nerve root avulsion was performed based on established methodologies [3]. Briefly, mouse was anesthetized by i.p. injection of sodium pentobarbital (40-50 mg/kg, Shanghai reagent company, Shanghai, China), then was put in prostate position. Incision was made from the occiput to the scapular angulus superior with $4 \mathrm{~cm}$ in length. When the muscles were drawn to one side, spinal cord was gently pulled to the left side, the left radix dorsails and radix ventralis from $\mathrm{C} 5$ to $\mathrm{T} 1$ were exposed and the nerve roots were avulsed from spinal cord. Animal's body temperature was maintained at $37^{\circ} \mathrm{C}$ throughout the experiment, no post-operation infection occurred. 1, 3 and 6 months later, animals were scarified by decapitation, and brain tissue were removed and stored rapidly.

\section{BiostarM-140 s microarray}

For mRNA isolation, cortex, brainstem and spinal cord were dissected and pooled from five animals in each group, which was to decrease differences attributable to individual variability and increase the statistically power of these experiments. Tissue were mechanically homogenized, mRNA was extracted by UNIzol reagent. After that, mRNA was treated with RNase-free DNase I (Takara, Japan). BiostarM-140 s microarray was performed, which contains probe sets for detection of
14,000 transcripts. The mRNA was labeled in a reverse transcription reaction in the presence of Cy3-dCTP and Cy5-dCTP. The hybridization signals were scanned with ScanArray 4000, each set of gene expression (operation/ control) was expressed as ratio of Cy3 to Cy5. Data processing was performed on GenePix Pro 3.0. All arrays were normalized together as one experiment to reduce non-biological variability.

\section{Real time PCR}

Cerebral cortex, brainstem and spinal cord were dissected ( $50 \mathrm{mg}, \mathrm{n}=5$ ), mRNA was extracted by UNIzol reagent and treated with RNase-free DNase I (Takara, Japan). Reverse transcription using random hexamers was performed with Omniscript reverse transcriptase (QIAGEN). Briefly, 20- $\mu$ l reactions contained DNasetreated RNA, deoxynucleoside triphosphate mix, $1 \mu \mathrm{M}$ random hexamer primer, $1 \mathrm{U}$ of RNase inhibitor (Ambion), and Omniscript reverse transcriptase. Reactions incubated at $37^{\circ} \mathrm{C}$ for $1 \mathrm{~h}$, followed by $93^{\circ} \mathrm{C}$ inactivation for $5 \mathrm{~min}$.

Real time PCR analysis was performed with SYBR Green I (Takara, Japan). Briefly, $50 \mu \mathrm{l}$ reactions contained cDNA; $0.5 \mu \mathrm{M}$ of primers specific for IL-1 $\beta$ (sense: 5'-CTCCATGAGCTTTGTACAAGG-3'; antisense: 5'-TGCTGATGTACCAGTTGGGG-3'), IL-6 (sense: 5'-CTCTCCGCAAGAGACTTCCA-3'; antisense: 5'-TGGTCTTCTGGAGTTCCGTT-3'), RGS4 (sense: 5'CCGGCTTCTTGCTTGAGGAGTG-3'; antisense: 5'ATCCAGGTTCACATTCATGACT-3'), PKAC $\beta$ (sense: 5'-AGAAAGCAGGCACTCGTACA-3'; antisense: 5'AAAGGAGACCGAAAACATGG-3'); $25 \mu \mathrm{l}$ PCR master mix. PCR was performed in ABI PRISM 7900HI (Applied Biosystems) as follows: $50^{\circ} \mathrm{C}$ for $2 \mathrm{~min}$ and $95^{\circ}$ $\mathrm{C}$ for $10 \mathrm{~min}$, followed by 40 cycles of $95^{\circ} \mathrm{C}$ for $15 \mathrm{sec}$ and $60^{\circ} \mathrm{C}$ for $1 \mathrm{~min}$. Endogenous control (GAPDH) was used for each sample in the same plate, minimizing any effect of plate-to-plate variability. Gene expression was quantified with the $2-\Delta \Delta \mathrm{Ct}$ method, which computed the percentage change relative to control.

\section{ELISA analysis of IL-1 $\beta$ and IL- 6 production}

IL- $1 \beta$ and IL- 6 production in brainstem $(50 \mathrm{mg}$ ) were assessed by sandwich ELISA according to the manufacturer's instructions (R\&D Systems). A 96-well plate was coated with $2 \mu \mathrm{g} / \mathrm{ml}$ monoclonal anti-mouse IL-1 $\beta$ or IL-6 at $4^{\circ} \mathrm{C}$ overnight and then blocked with $1 \%$ BSA in PBS for $1 \mathrm{~h}$. The plates were washed three times with PBS containing $0.2 \%$ Tween 20 (PBST). Aliquots of tissue lysate was diluted to $100 \mu \mathrm{l}$ with HBSS, added to the plates, and incubated for $2 \mathrm{~h}$ at room temperature. The plates were washed three times with PBS, $100 \mu \mathrm{l}$ aliquots of $0.1 \mu \mathrm{g} / \mathrm{ml}$ biotinylated mouse IL- $1 \beta$ or IL- 6 affinity-purified polyclonal detection antibody were 
added and incubated for $2 \mathrm{~h}$. After further three washes with PBST, the immune complexes were colorimetrically detected using HRP-streptavidin conjugate. The reaction was stopped by $1 \mathrm{M} \mathrm{H}_{2} \mathrm{SO} 4$. The absorbance at $450 \mathrm{~nm}$ in each well was measured by microplate reader (BioRad). Experiments were independently performed three times and the data are represented as the mean \pm SEM.

\section{Preparation of plasma membrane and non-membrane fraction}

Cerebral cortex, brainstem and spinal cord from each group of mice, or neurons $\left(1 \times 10^{6}\right)$ undergone respective treatment were homogenized in 3-4 volumes $(\mathrm{w} / \mathrm{v})$ of homogenization buffer $(0.32 \mathrm{M}$ sucrose, $2 \mathrm{mM}$ Na-EGTA, 1 mM NaN3, 5 pg/ml leupeptin, 5 pg/ml pepstatin A, $200 \mathrm{pg} / \mathrm{ml}$ phenylmethylsulfonyl fluoride, and $0.01 \%(\mathrm{v} / \mathrm{v})$ DFP, $\mathrm{pH} 7.5)$ and centrifuged at $900 \mathrm{~g}$ for $10 \mathrm{~min}$. The supernatant (S1) was pelleted for $1 \mathrm{~h}$ at $30,000 \mathrm{~g}$, then was washed with phosphate/EGTA buffer (10 mM sodium phosphate, $2 \mathrm{mM}$ Na-EGTA, $1 \mathrm{mM}$ NaN3, $0.5 \mathrm{mM}$ DTT, $50 \mathrm{pg} / \mathrm{ml}$ phenylmethylsulfonyl fluoride, $\mathrm{pH}$ 7.5) and resuspended at a final membrane protein concentration of 3-4 $\mathrm{mg} / \mathrm{ml}$, which was used as membrane fraction. S1 was collected and total protein was precipitated by $5 \%$ Trichloroacetic acid (TCA), which was used as non-membrane fraction. RGS4 expression in each fraction was analyzed by Western Blot.

\section{Primary neuron culture}

Brainstem neurons were from embryonic day 18 C57BL/6 mice. Fetuses were decapitated and collected under sterile conditions. After removing meninges, neurons were dissociated in $0.05 \%$ trypsin at $37^{\circ} \mathrm{C}$, then washed in DMEM and gently suspended in neuron-defined serum-free Neurobasal medium supplemented with B27. By flow cytometry, neurons were account for $95 \%$ of cultures.

\section{Detergent-free preparation of lipid rafts}

The isolation of lipid rafts in the current study was adapted from Lisanti's lab $[16,17]$. Neurons were scraped into $2 \mathrm{ml}$ of $500 \mathrm{mM}$ sodium carbonate, PH11.0. Homogenization was carried out sequentially in the following order using a loose-fitting Dounce homogenizer (10 strokes), three 10-sec bursts of a Polytron tissue grinder (Brinkmann Instruments, Inc., Westbury, NY) at setting 6 , followed by one 30 -sec burst at setting 4 and one 30-sec burst at setting 8 of a sonicator equipped with a micro-probe (Heat systems-Ultrasonics, Inc., Plainview, NY). The homogenate was then adjusted to $45 \%$ sucrose by the addition of $2 \mathrm{ml}$ of $90 \%$ sucrose prepared in MBS at $\mathrm{pH} 6.8$ and placed at the bottom of an ultracentrifuge tube. The lysate was then overlaid with $4 \mathrm{ml}$ of $35 \%$ sucrose and $4 \mathrm{ml}$ of $5 \%$ sucrose, both prepared in MBS containing $250 \mathrm{mM}$ sodium carbonate at $\mathrm{pH} 11$. The discontinuous gradient was centrifuged at 39,000 rpm for $16-20 \mathrm{hr}$ in a SW41 rotor. A light-scattering band to the $5-35 \%$ and $35-45 \%$ sucrose interface was collected and the total proteins were separated and analyzed by Western Blot.

\section{Western blotting}

Proteins were resolved in SDS-PAGE gel, then transferred to a polyvinylidene difluoride membrane (GE Healthcare, Little Chalfont, Buckinghamshire, UK). The membrane was blocked in a blocking solution containing 10\% non-fat milk and 1\% Tween 20 in Tris-buffered saline, and probed with RGS4 (1:1000), PKAC $\beta$ (1:1000) respectively. Protein band was detected by alkaline phosphatase conjugated secondary antibody (1:5000) and ECF substrate, and scanned in the Storm 860 Imaging System (GE Healthcare). Band intensities were quantified and analyzed with ImageQuant software (GE Healthcare).

\section{Statistical analysis}

Gene ontology, as well as the information about specific genes of interest was obtained from Pubmed. Intensity ratio of cy3 to cy 5 was presented for one gene, that was more than 2.0 or less than 0.5 was considered to show prominent differential expression. Results from ELISA, real time PCR and Western Blot were presented as means \pm SEM of three experiments. Statistical significance was determined using one-way ANOVA.

\section{Results}

\section{Regulated genes in cortex, brainstem and spinal cord}

The first step in this study was to screen genes that are regulated by brachial plexus avulsion, the comparison of genes allowed us to narrow down the candidates possibly involved in this process. In cerebral cortex, significant upregulation of 0,17 and 9 transcripts and downregulation of 49, 12 and 4 transcripts were exhibited after 1, 3 and 6 months of brachial plexus avulsion (Additional file 1). When putting the regulated genes into a functional context, we found that several key genes involved in signal transduction. For example, genes encoding casine kinase, potassium voltage-gated channel and heat shock protein were up-regulated in 3 month. Besides that, clusters of genes involved in cell signaling, cell structure, stress and immune responses, such as genes encoding for protein $\mathrm{C}$ receptor, angiotensin, plastaglandin E, microtubule associated protein $1 \mathrm{~B}$, tubulin, PKAC $\beta$ and RGS4 were induced by brachial plexus avulsion.

In brainstem, there were 40 (8 up, 32 down), 11 (7 up, 4 down), 137 (63 up, 74 down) transcripts were significantly regulated in 1,3 and 6 months of brachial plexus avulsion (Additional file 2). PKAC $\beta$ and RGS4 are 
among the upregulated genes. Other regulated genes are several involved in immune reaction and signal transduction, including microtubule associated protein $1 \mathrm{~B}$, tubulin, and tyrosine ligase, cytochrome P450, thymopoietin, PDZ domain, novel nuclear protein, immunoglobulin family, major histocompatibility complex, angiotensin 2, dual-specificity tyrosine kinae, G-protein coupled receptor 56, FK506 binding protein, N-ras protein, phospholipids D, cytoskeleton associated protein, dynactin, forming binding protein, serine peptidase inhibitor, tenascin, low density lipoprotein receptor, TRIP$\mathrm{Br} 1$, glia maturation factor, peroxisome proliferators activated receptor.

In spinal cord, we found an upregulation of 14, 18 and 29 transcripts and downregulation of 13, 15 and 31 transcripts in 1, 3 and 6 month of brachial plexus avulsion (Additional file 3). Several regulated genes were related to synaptic function, such as synaptotagmin, synaptobrevin and protein tyrosine phosphatase. Some were associated with cell metabolism, such as glutamate-cycteine ligase. PKAC $\beta$ and RGS4 were the remarkable upregulated genes.

\section{IL-1 $\beta$ and IL- 6 production in the central nervous system by brachial plexus avulsion}

Constitutive expression of IL-1 $\beta$ and IL- 6 in brain is quite low in basal condition [18]. Based on cDNA microarray data, they could be induced by brachial plexus avulsion with region specific manner. To determine whether this differential regulation occurs only in brainstem, quantification by means of real-time PCR and ELISA assay were performed. We observed a significant up-regulation of IL-1 $\beta$ and IL- 6 mRNA expression in brainstem, they were $4.37 \pm 0.56$ and $4.06 \pm 0.49$, $3.97 \pm 1.38$ and $3.51 \pm 1.54,3.89 \pm 0.32$ and $3.50 \pm 1.46$ folds of control in 1, 3 and 6 month of operation respectively (Figure 1A). But no changes displayed in cortex and spinal cord (data not shown). IL-1 $\beta$ and IL-6 protein content in brainstem were also elevated $(4.57 \pm$ 1.51 and $3.77 \pm 1.35,4.10 \pm 1.44$ and $3.52 \pm 1.54,4.07 \pm$ 1.51 and $3.49 \pm 1.43$ folds of control), which clearly matched with their mRNA level (Figure 1B).

\section{Confirmation of PKAC $\beta$ and RGS4 gene expression by real-time PCR}

The findings by cDNA microarray highlight the complexity in gene expression changes that triggered by brachial plexus avulsion. To validate the genes which are potentially associated with IL- $1 \beta$ signaling, we focused on the genes encoding RGS4 and PKAC $\beta$ on account of their overall regulation in cortex, brainstem and spinal cord (Table 1). As illustrated in Figure 2, RGS4 and PKAC $\beta$ mRNA expression in cerebral cortex was $1.02 \pm$ 0.17 and $0.97 \pm 0.21,2.77 \pm 0.34$ and $2.97 \pm 0.48,2.59 \pm$
0.39 and $3.12 \pm 1.13$ folds of control in 1,3 and 6 month of operation respectively. In brainstem, they were $0.99 \pm 0.21$ and $1.03 \pm 0.28,2.97 \pm 0.39$ and $3.02 \pm$ $1.04,3.12 \pm 1.21$ and $2.80 \pm 1.13$ folds of control. In spinal cord, they were $0.99 \pm 0.21$ and $0.97 \pm 0.20,2.79$ \pm 0.34 and $3.13 \pm 1.10,2.92 \pm 0.21$ and $3.09 \pm 1.07$ folds of control respectively. The results are correlated very well with the data obtained from microarray analysis.

\section{Modulation of RGS4 membrane distribution by brachial plexus avulsion}

Since the regulation of RGS4 was dependent on its phosphorylation and subcelllular distribution [19], we determined to examine RGS4 expression profiles when challenged with brachial plexus avulsion. As shown in Figure 3, membrane distribution of RGS4 in cerebral cortex and spinal cord began to increase in 3 and 6 month of nerve injury. The relative densities to control were $0.97 \pm 0.23,2.77 \pm 0.35,2.92 \pm 0.21$ folds of control in cortex, $1.03 \pm 0.22,2.98 \pm 1.08,2.83 \pm 1.09$ folds of control in spinal cord in 1, 3 and 6 month of nerve injury respectively. However, in brainstem, elevated RGS4 was mainly concentrated in non-membrane fraction, the relative densities to control were $1.05 \pm$ $0.23,3.03 \pm 0.52,2.90 \pm 0.38$ folds of control in the three time points.

\section{Modulation of RGS4 membrane distribution in cultured neuron}

Whether IL-1 $\beta$ or PKAC $\beta$ controlled RGS4 subcellular distribution? As displayed in Figure 4, RGS4 was localized within non-membrane fraction in cultured neurons in basal condition. Administration of cAMP analogue dibutyryl-cAMP (dbcAMP, $0.25 \mathrm{mM}, 24 \mathrm{~h}$ ) resulted in RGS4 translocated into membrane fraction, the relative density to vehicle treatment was $2.93 \pm 0.37$ folds of control. In contrast, PKA inhibitor, KT5720 (9-n-hexyl derivative of K-252a, $10 \mu \mathrm{M}, 30 \mathrm{~min}$ ) exposure attenuated RGS4 membrane distribution, the relative density was $1.02 \pm 0.30$ folds of control. Similar observation was also obtained on the neurons collected from cortex and spinal cord (data not shown).

However, what the mechanism underlying the role of IL-1 $\beta$ on the RGS4 membrane distribution? Figure 4 illustrated that relative density of RGS4 in membrane fraction was attenuated when exposed to IL-1 $\beta$ (20 ng/ $\mathrm{ml}, 24 \mathrm{~h})(0.51 \pm 0.11$ folds of control). IL-1 receptor antagonist (IL-1ra, $10 \mathrm{ng} / \mathrm{ml}, 24 \mathrm{~h}$ ) showed significant inversely effect, the relative density of RGS4 was elevated to $2.76 \pm 0.38$ folds of control. Discontinuous sucrose density centrifugation is designed to specifically quantify the PKAC $\beta$ distribution within lipid rafts. Notably, IL-1 $\beta$ treatment leads to the decreased 
A

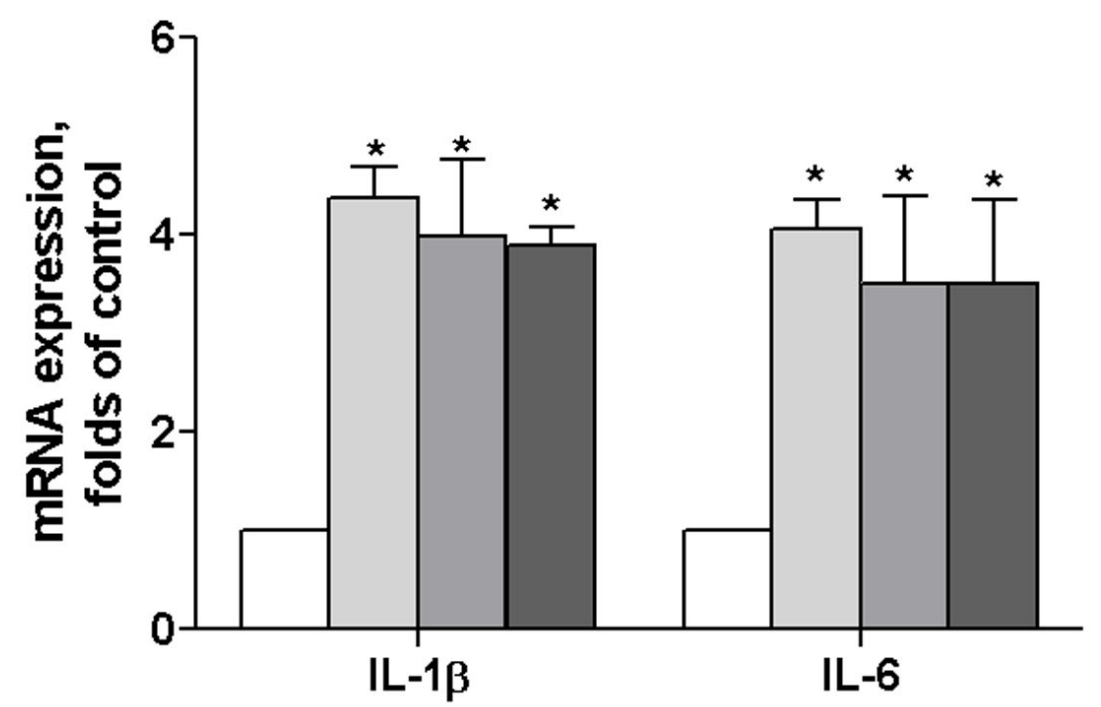

B

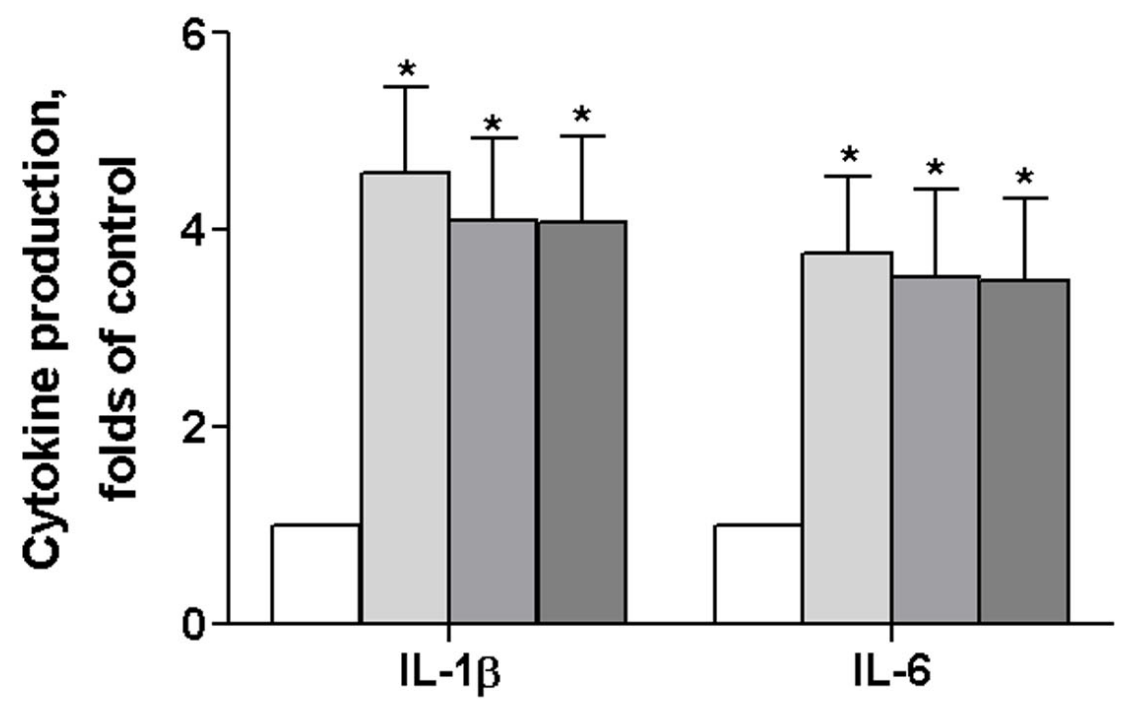

Figure 1 Kinetic changes in IL-1 $\beta$ and IL- 6 expression in brainstem after brachial plexus avulsion. Mice were divided into 4 groups, control, 1,3 and 6 month of brachial plexus avulsion $(n=5)$. IL-1 $\beta$ and IL-6 mRNA expression (A) and protein content (B) in brainstem were evaluated by real time PCR and ELISA assay respectively. The results were normalized against un-operated mouse, data are expressed as mean \pm SEM. $p<0.05 *$ vs control.

PKAC $\beta$ expression in lipid raft microdomain, relative density was $0.52 \pm 0.14$ folds of $\%$ control. IL-1ra could reverse the effect of IL-1 $\beta$, PKAC $\beta$ lipid rafts distribution was restored $(0.92 \pm 0.24$ folds of control). Also, IL-6 content in neuron is efficiently controlled by IL- $1 \beta$.

\section{Discussion}

Previous study have implicated that peripheral nerve injury induced reorganization is not equally distributed across the neuroaxis. The acute effects of nerve injury appear to be much more pronounced in the brainstem than in cortex [20], while the more protracted phase of 
Table 1 Genes with confirmed up- or down-regulation

\begin{tabular}{|c|c|c|c|}
\hline & 1 month & 3 month & 6 month \\
\hline \multicolumn{4}{|l|}{ Regulated in the motor cortex } \\
\hline regulator of G-protein signaling 4 (NM_009062) & & $\uparrow$ & $\uparrow$ \\
\hline protein kinase, CAMP dependent regulatory (NM_008923) & & $\uparrow$ & $\uparrow$ \\
\hline \multicolumn{4}{|l|}{ Regulated in the brain stem } \\
\hline IL-1 protein (AJ250429) & $\uparrow$ & $\uparrow$ & $\uparrow$ \\
\hline interleukin 6 signal transducer (BC058679) & $\uparrow$ & $\uparrow$ & $\uparrow$ \\
\hline regulator of G-protein signaling 4 (NM_009062) & & $\uparrow$ & $\uparrow$ \\
\hline \multicolumn{4}{|l|}{ Regulated in the spinal cord } \\
\hline regulator of G-protein signaling 4 (NM_009062) & & $\uparrow$ & $\uparrow$ \\
\hline protein kinase, CAMP dependent regulatory (NM_008923) & & $\uparrow$ & $\uparrow$ \\
\hline
\end{tabular}

Mice were divided into 4 groups, control, 1, 3 and 6 month of brachial plexus avulsion $(n=5)$. Cerebral cortex, brainstem and spinal cord were dissected (50 mg, $\mathrm{n}=5$ ), mRNA was extracted and Real time PCR analysis was performed with SYBR Green I. Endogenous control (GAPDH) was used for each sample in the same plate, minimizing any effect of plate-to-plate variability. Gene expression was quantified with the $2-\Delta \Delta C t$ method, which computed the percentage change relative to control.

effects appears to result from differing extents of secondary functional changes, as well as the more dynamic interactive processes in cortex $[21,22]$. Thus, it will be interesting to validate the putative targets, by which fine-tuned a spatio-temporal reorganization following brachial plexus avulsion.

In this study, application of microarray analyses, we found that 49 (0 up, 49 down), 29 (17 up, 12 down), 13 (9 up, 4 down) genes in cortex were changed in 1,3 and 6 months of brachial plexus avulsion. In brainstem, 40 (8 up, 32 down), 11 (7 up, 4 down), 137 (63 up, 74 down) genes were identified. Some of these genes are involved in axonal transport, which would be expected to closely link to the actin projection cut down $[23,24]$. Moreover, the alteration pointed to the hypothesis that the injured environment was dominated by deafferentation induced responses, neural tissue was surrounded by stimulated fibers and reorganized vasculature [25]. In spinal cord, 27 (14 up, 13 down), 33 (18 up, 15 down), 60 (29 up, 31 down) genes were identified. Upregulation of synaptotagmin, synaptobrevin and protein tyrosine phosphatase signified the increased synaptic efficacy and formation of new synaptic buttons of the existing projections $[26,27]$, which might pinpoint the compensatory mechanisms.

Notably, we found that the changes occur after brachial plexus avulsion is relatively specific in the brainstem, IL$1 \beta$ and IL-6 displayed differential expression profile in brainstem compared with cortex and spinal cord. Based on the report, IL- $1 \beta$ and IL- 6 are associated with many brain functions [18]. For example, they have been implicated in the excessive production and processing of $\beta$-amyloid precursor protein and the plaque-associated proteins [28]; They can induce the production of various growth and trophic factors, including fibroblast growth factor-2 (FGF-2) [29], transforming growth factor- $\beta$ (TGF- $\beta$ ) [30], and nerve growth factor (NGF) [31]; They can also stimulate inflammatory mediators, such as phospholipase A2, cyclooxygenase-2 (Cox-2), prostaglandins, nitric oxide, matrix metalloproteinases, collagenase [18], adhesion molecule and other cytokines [32,33]. Combined with our present data, it is reasonable to propose that the orchestrated IL- $1 \beta$ and IL- 6 expression induced by brachial plexus avulsion are likely responsible for setting up the cytokines networks.

It is even more striking that RGS4 and PKAC $\beta$ expression were up-regulated in 3 and 6 month of brachial plexus avulsion, the elevation occurred overall in cortex, brainstem and spinal cord. As well known, heterotrimeric G proteins transduce signals from a wide range of hormone and neurotransmitter receptors at the cell surface to the intracellular environment. Following activation, G proteins interact with well-defined effectors such as phopholipase $\mathrm{C}$, adenylyl cyclase, a number of ion channels and RGS proteins $[34,35]$. RGS proteins is defined by a conserved 130 amino acid RGS domain, which serve as a GTPase activating protein (GAP) by binding to activated Ga subunits [36,37]. Now, RGS superfamily has more than 30 distinct mammalian proteins, RGS4 has densely labeling in cortex, thalamus and striatum [19]. Kinase activity could affect RGS proteins stability, their interaction with $G \alpha$ subunits, or their cellular trafficking $[38,39]$. It has also revealed that RGS phosphorylation appears to be related to its subpopulation of intracellular vesicles [40]. For example, when RGS2 was phosphorylated by PKC, GAP activity was reduced, then Gq/11 signals were enhanced [41]; RGS16 phosphorylation could also reduce its GAP activity toward GRi/o and result in increased adrenergic receptor signals [42], then the paralleled increase in RGS4 and PKA induced by brachial plexus avulsion will be expected to unmask their full functional potential, the orchestrated and dynamical RGS4 subcellular distribution and modulation will be the intriguing intracellular signal in response to brachial 
A

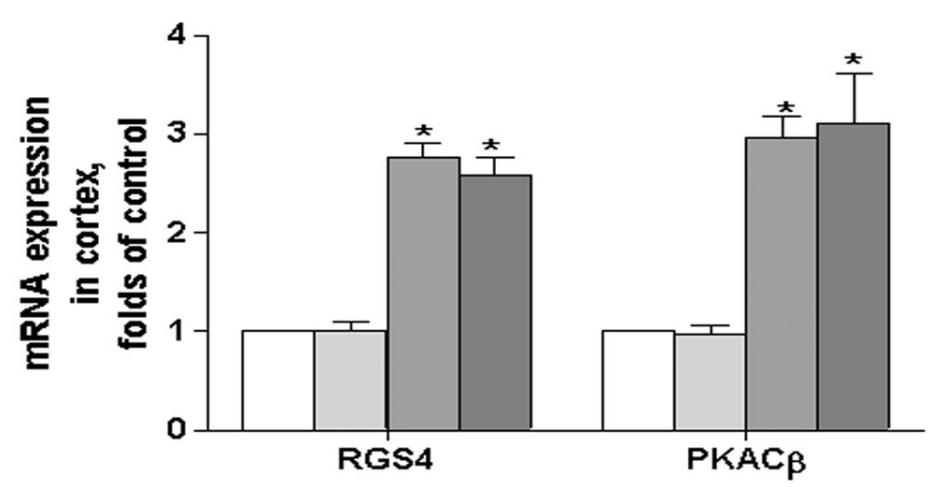

B

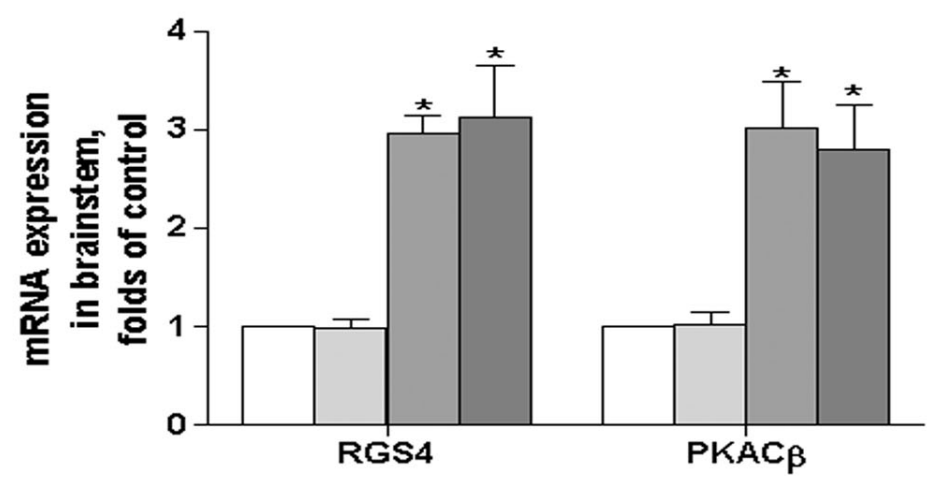

C

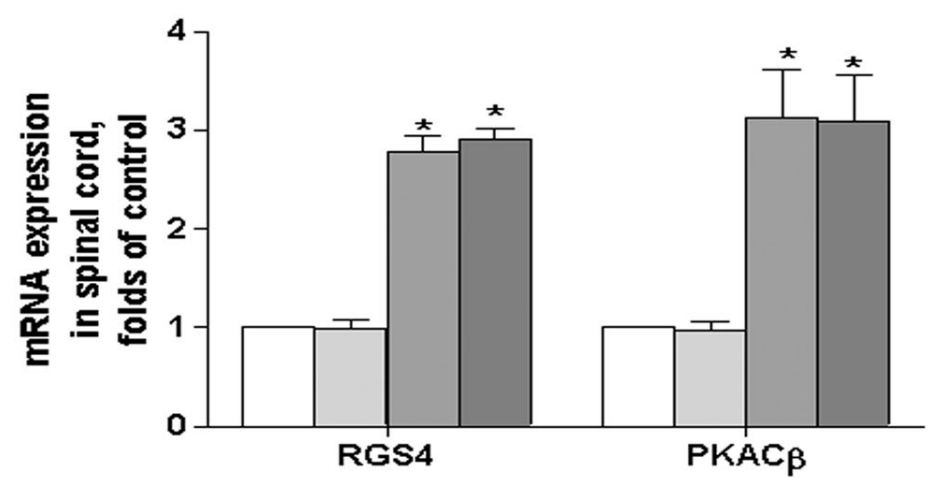

Figure 2 Kinetic changes in RGS4 and PKAC $\beta$ expression in brainstem after brachial plexus avulsion. Mice were divided into 4 groups, control, 1, 3 and 6 month of brachial plexus avulsion $(n=5)$. RGS4 and PKAC $\beta$ mRNA expression in cortex (A), brainstem (B) and spinal cord (C) were assayed by real time PCR. The results were normalized against un-operated mouse, data are expressed as mean \pm SEM. $\mathrm{p}<0.05 *$ VS control.

plexus avulsion. Our findings support this hypothesis: RGS4 was mainly expressed in membrane fraction in cortex and spinal cord, in non-membrane fraction in brainstem. Since PKAC $\beta$ expression was along with RGS4, it is speculated that RGS4 differential expression profile may be due to their relevance. As expected, direct analyzing using cultured neuron displayed that RGS4 membrane distribution was dependent on PKA activation.

Several studies have documented that CAMP-CREB pathway is highly involved in brain inflammatory 
A

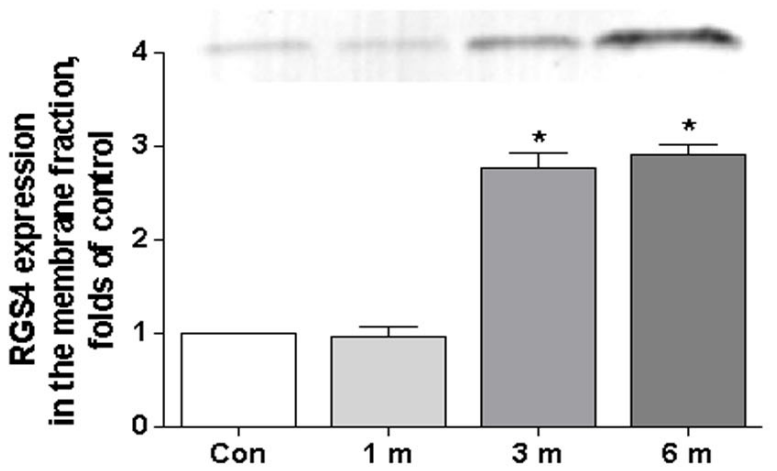

B
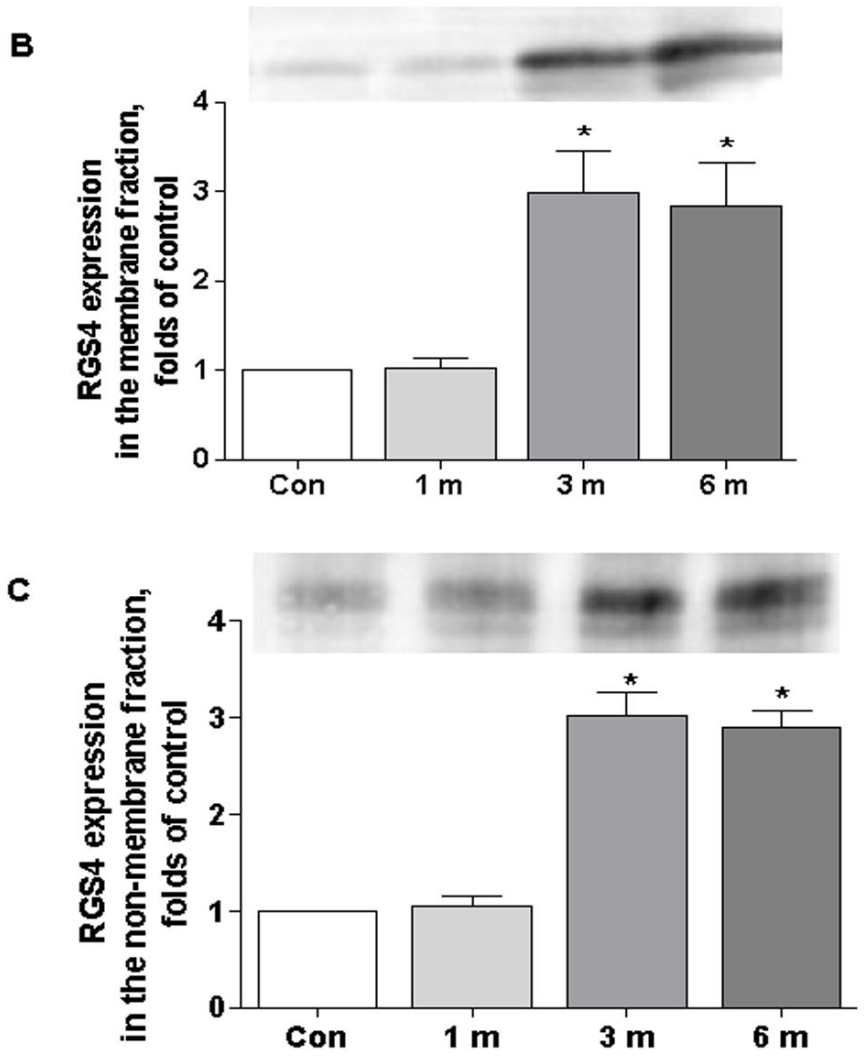

Figure 3 Modulation of RGS4 membrane distribution by brachial plexus avulsion. Mice were divided into 4 groups, control, 1,3 and 6 month of brachial plexus avulsion $(n=5)$. Western blot analysis of RGS4 in the membrane fraction collected from cortex (A) and spinal cord (B), in the non-membrane fraction in brainstem (C). RGS4 protein was densitometric analyzed and normalized against un-operated mouse, data are expressed as mean \pm SEM. $p<0.05 *$ vs control.

processes, whose cellular responses to neurotransmitters, synaptic plasticity, differentiating factors and stressors were mainly concentrated in lipid rafts [43-45]. IL-1 $\beta$-IL-6 signaling in neuron are known to be the upstream of cAMP and CREB $[46,47]$. In the present study, IL-1 $\beta$ could disrupt RGS4 membrane distribution by promoting PKA shuttle out of lipid rafts. We therefore presumed that the alteration in RGS4 membrane turnover in brainstem was derived from the presence of IL-1 $\beta$. There might exist alternative RGS4 related signaling pathway in cortex, spinal cord and brainstem. 
A

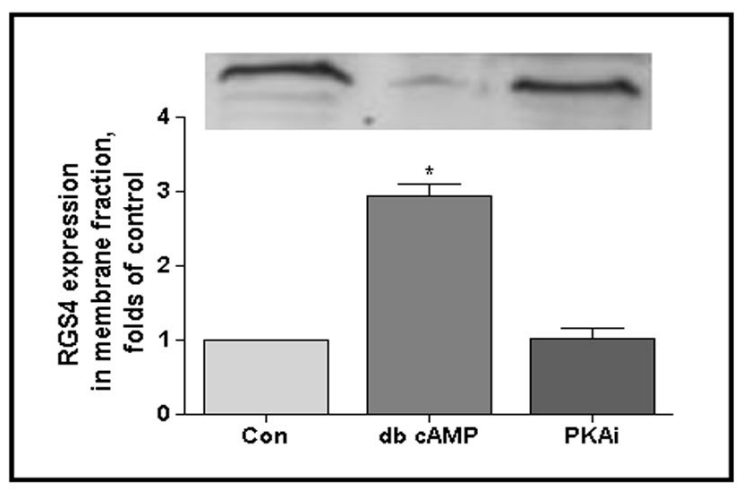

C

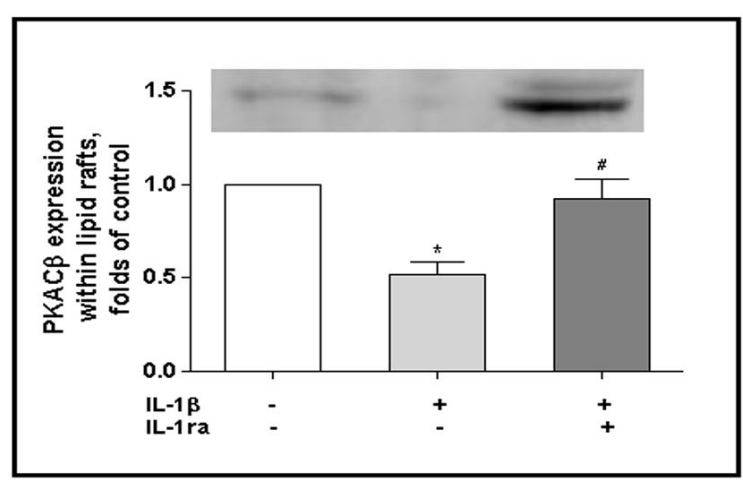

B

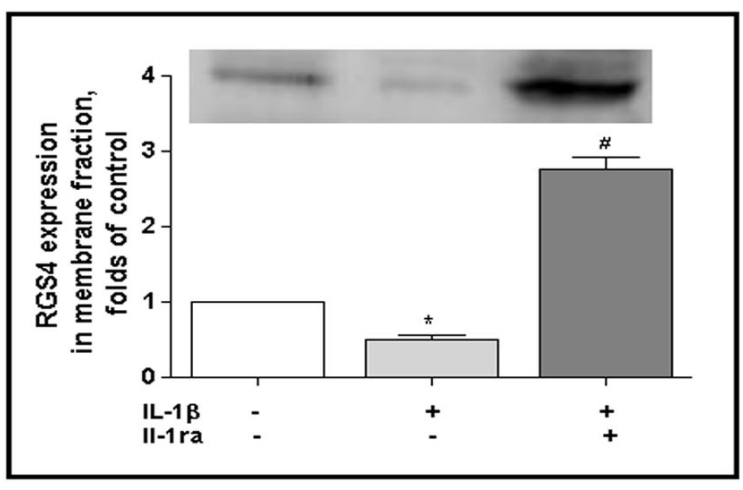

$\mathrm{D}$

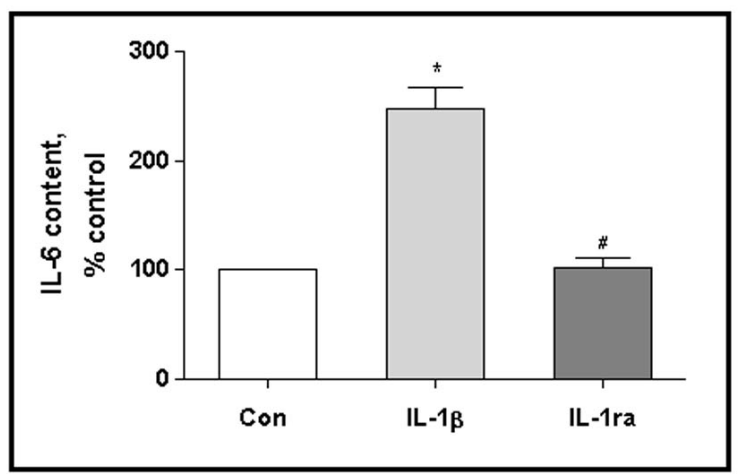

Figure 4 Modulation of RGS4 membrane distribution in cultured neuron. Cortical neurons were grown for 10 days, then RGS4 subcellular distribution in the presence or absence of db CAMP, KT5720 (A); IL-1 $\beta$, IL-1ra (B) was assayed by Western blotting. The localization of PKC $\beta$ within lipid rafts microdomain was assayed by discontinuous sucrose centrifugation and Western blotting (C). IL-6 content in the presence or absence of IL-1 $\beta$, IL-1 ra was evaluated by ELISA assay (D). The results were normalized against vehicle treated neurons. Statistical differences were evaluated by ANOVA analysis.* $\mathrm{p}<0.05$ vs control.

Altogether, these data support the ability of brachial plexus avulsion on the brain reorganization. After nerve injury, coordinated tissue remodeling and amplified the mounting cellular response in cortex, brainstem and spinal cord was efficiently initiated and perpetuated. IL-1 $\beta$-IL-6 signaling in brainstem in the early stage (1 month) appears to enhance the perceptions of compensatory modalities, and may serve to reinforcement of feedback activity in response to nerve injury. In the later stage ( 3 and 6 month), it may triggered differed Gprotein signal events within CNS, which might consequently function to re-establish or strengthening of the local circuits at cortical and subcortical levels.

\section{Conclusion}

The present study showed that brachial plexus avulsion lead to both specific as well as more global changes in gene expression in cortex, brainstem and spinal cord. The regulated genes at acute or longer times display interesting similarities or differences among the three brain regions, which may contribute to the different aspects of brain responses to brachial plexus avulsion. For example, IL-1 $\beta$ and IL-6 expression were upregulated only in brainstem, while RGS4 and PKAC $\beta$ expression could be induced overall in cortex, brainstem and spinal cord. Importantly, RGS4 displayed differential distribution, namely, in membrane fraction in cortex and spinal cord, while in non-membrane fraction in brainstem. This subcellular distribution was dependent on the functional correlation between IL- $1 \beta$ and PKAC $\beta$. Thereby, we assumed that temporal and spatial IL-1 $\beta$ IL-6 signaling in brain might function to re-establish or strengthening of the local circuits at cortical and subcortical levels. 


\section{Additional material}

Additional file 1: Functional classification of the annotated genes that show differentiated expressions in the motor cortex following brachial plexus axotomy. Intensity ratio of cy3 to cy 5 was presented for one gene, that was more than 2.0 or less than 0.5 was considered to show prominent up- or down-regulated expression.

Additional file 2: Functional classification of the annotated genes that show differentiated expressions in the brain stem following brachial plexus axotomy. Intensity ratio of cy3 to cy5 was presented for one gene, that was more than 2.0 or less than 0.5 was considered to show prominent up- or down-regulated expression.

Additional file 3: Functional classification of the annotated genes that show differentiated expressions in the spinal cord following brachial plexus axotomy. Intensity ratio of cy3 to cy 5 was presented for one gene, that was more than 2.0 or less than 0.5 was considered to show prominent up- or down-regulated expression.

\section{Abbreviations}

CAMP: cyclic AMP; CNS: central nervous system; CREB: CAMP response element-binding protein; GAP: GTPase activating protein; IL-1 $\beta$ : interleukin $1-\beta$; IL-6: interleukin-6; PKAC $\beta$ : protein kinase A catalytic subunit $\beta$; RGS4: regulator of $\mathrm{G}$ protein signaling 4 .

\section{Authors' contributions}

$\mathrm{HZ}$ did design, data acquisition, analysis, and writing. YG and JL revised the manuscript. PL did animal experiment. All approved the final version.

\section{Competing interests}

The authors declare that they have no competing interests.

Received: 4 June 2010 Accepted: 7 December 2010

Published: 7 December 2010

\section{References}

1. Navarro X, Vivo M, Valero-Cabre A: Neural plasticity after peripheral nerve injury and regeneration. Progrss Neurobiol 2007, 82:163-201.

2. Rosberg HE, Carlsson KS, Dahlin LB: Prospective study of patients with injuries to the hand and forarm: costs, function and general health. Scand J Plast Reconstr Surg Hand Surg 2005, 39:360-369.

3. Lou L, Shou T, Li W, Gu Y: Transhemispheric functional reorganization of the motor cortex induced by the peripheral contralateral nerve transfer to the injured arm. Neuroscience 2006, 138:1225-1231.

4. Wall JT, Xu J, Wang X: Human brain plasticity: an emerging view of the multiple substrates and mechanisms that cause cortical changes and related sensory dysfunctions after injuries of sensory inputs from the body. Brain Res Rev 2002, 39:181-215.

5. Jaquet JB, Luijsterburg AJ, Kalmijin S, Kuypers PD, Hofman A, Hovius SE: Median, Ulnar, and combined median-ulnar nerve injuries: functional outcome and return to producticivity. J trauma 2001, 51:687-692.

6. Winkelstein BA, Rutkowski MD, Sweitzer SM, Pahl JL, DeLeo JA: Nerve injury proximal or distal to the DRG induces similar spinal glial activation and selective cytokine expression but differential behavioral responses to pharmacologic treatment. J Comp Neurol 2001, 439:127-39.

7. Johnson EO, Vekris MD, Zoubos AB, Soucacos PN: Neuroanatomy of the brachial plexus: the missing link in the continuity between the central and peripheral nervous systems. Microsurgery 2006, 26:218-229.

8. Rodrigues-Filho R, Campos MM, Ferreira J, Santos ARS, Bertelli JA, Calixto JB: Pharmacological characterisation of the rat brachial plexus avulsion model of neuropathic pain. Brain Res 2004, 1018:159-170.

9. Pagni CA, Canavero S: Pain, muscle spasms and twitching fingers following brachial plexus avulsion-report of three cases relieved by dorsal root entry zone coagulation. J Neurol 1993, 240:468-470.

10. Chikanza IC, Grossman AB: Neuroendocrine immune responses to inflammation: the concept of the neuroendocrine immune loop. Baillieres Clin Rheumatol 1996, 10:199-225.
11. Ballou LR, Barker SC, Postlethwaite AE, Kang AH: Sphingosine potentiates IL-1-mediated prostaglandin E2 production in human fibroblasts. J Immunol 1990, 145:4245-51.

12. Lu J, Goh SJ, Tng PY, Deng YY, Ling EA, Moochhala S: Systemic inflammatory response following acute traumatic brain injury. Front Biosci 2009, 14:3795-813.

13. Tu Y, Wilkie TM: Allosteric regulation of GAP activity by phospholipids in regulators of G-protein signaling. Methods Enzymol 2004, 389:89-105.

14. Hu W, Li F, Mahavadi S, Murthy KS: Interleukin-1 beta up-regulates RGS4 through the canonical IKK2/lkappaBalpha/NF-kappaB pathway in rabbit colonic smooth muscle. Biochem J 2008, 412:35-43.

15. Hu W, Li F, Mahavadi S, Murthy KS: Upregulation of RGS4 expression by IL-1\{beta\} in colonic smooth muscle is enhanced by ERK $1 / 2$ and p38 MAPK and inhibited by the PI3K/Akt/GSK3 beta\} pathway. Am J Physiol Cell Physiol 2009, 296:C1310-20.

16. Smart EJ, Ying Y, Mineo C, Anderson RGW: A detergentfree method for purifying caveolae and intracellular cholesterol trafficking. Proc Soc Exp Biol Med 1995, 213:150-177.

17. Song KS, Li SW, Okamoto T, Quilliam LA, Sargiacomo M, Lisanti MP: Copurification and direct interaction of Ras with caveolin, an integral membrane protein of caveolae microdomains. A detergent-free purification of caveolae microdomains. J Biol Chem 1996, 271:9690-9697.

18. Rothwell NJ, Luheshi GN: Interleukin 1 in the brain: biology, pathology and therapeutic target. Trends Neurosci 2000, 23:618-25.

19. Saugstad JA, Marino MJ, Folk JA, Hepler JR, Conn PJ: RGS4 inhibits signaling by group I metabotropic glutamate receptors. $G$ proteincoupled receptors stimulation and the control of cell migration. J Neurosci 1998, 18:905-13.

20. Churchill JD, Arnold LL, Garraghty PE: Somatotopic reorganization in the brain stem and thalamus following peripheral nerve njury in adult primates. Brain Res 2001, 910:142-152

21. Ebner FF, Erzurumlu RS, Lee SM: Neurobiology Peripheral nerve damage facilitates functional innervation of brain grafts in adult sensory cortex (peripheral regeneration/cortical plasticity/thalamocortical projections). Proc Natl Acad Sci USA 1989, 86:730-734.

22. Havton L, Kellerth JO: Plasticity of recurrent inhibitory reflexes in cat spinal motoneurons following peripheral nerve injury. Exp Brain Res 1990, 79:75-82.

23. Wong JW, MCPhail LT, Brastianos HC, Andersen RJ, Ramer MS, O'Connor TP: A novel diketopiperazine stimulates sprouting of spinally projecting axons. Exp Neurol 2008, 214:331-40.

24. Priestley JV: Promoting anatomical plasticity and recovery of function after traumatic injury to the central or peripheral nervous system. Brain 2007, 130:895-897.

25. Vestergaard S, Tandrup T, Jakobsen J: Effect of permanent axotomy on number and volume of dorsal root ganglia cell bodies. J Comp Neurol 1997, 388:307-312.

26. Chen DH: Qualitative and quantitative study of synaptic displacement in chromatolyzed spinal motorneurons of the cat. J Comp Neurol 1978, 177:635-664.

27. Kaas $\mathrm{JH}$, Collins CE: Anatomic and functional reorganization of somatosensory cortex in mature primates after peripheral nerve and soinal cord injury. Adv Neurol 2003, 93:87-95.

28. Yasojima K, Akiyama H, McGeer EG, McGeer PL: Reduced neprilysin in high plaque areas of Alzheimer brain: a possible relationship to deficient degradation of beta-amyloid peptide. Neurosci Lett 2001, 297:97-100.

29. Araujo DM, Cotman CW: Basic FGF in astroglial, microglial, and neuronal cultures: characterization of binding sites and modulation of release by lymphokines and trophic factors. J Neurosci 1992, 12:1668-78.

30. da Cunha A, Vitković L: Transforming growth factor-beta 1 (TGF-beta 1) expression and regulation in rat cortical astrocytes. J Neuroimmunol 1992, 36:157-69.

31. Lazarovici P, Rasouly D, Friedman L, Tabekman R, Ovadia H, Matsuda Y: K252a and staurosporine microbial alkaloid toxins as prototype of neurotropic drugs. Adv Exp Med Biol 1996, 391:367-77.

32. Mey J, Schrage K, Wessels I, Vollpracht-Crijns I: Effects of inflammatory cytokines IL-1beta, IL-6, and TNFalpha on the intracellular localization of retinoid receptors in Schwann cells. Glia 2007, 55:152-64.

33. Ozaki A, Nagai A, Lee YB, Myong NH, Kim SU: Expression of cytokines and cytokine receptors in human Schwann cells. Neuroreport 2008, 19:31-5. 
34. Chen M, Wang J, Dickerson KE, Kelleher J, Xie T, Gupta D, Lai EW, Pacak K, Gavrilova O, Golan M, Schreiber G, Avissar S: Antidepressants, betaarrestins and GRKs: from regulation of signal desensitization to intracellular multifunctional adaptor functions. Curr Pharm Des 2009, 15:1699-708

35. Crouthamel M, Thiyagarajan MM, Evanko DS, Wedegaertner PB: N-terminal polybasic motifs are required for plasma membrane localization of Galpha(s) and Galpha(q). Cell Signal 2008, 20:1900-10.

36. Anderson GR, Lujan R, Martemyanov KA: Changes in striatal signaling induce remodeling of RGS complexes containing Gbeta5 and R7BP subunits. Mol Cell Biol 2009, 29:3033-44.

37. Smith B, Hill C, Godfrey EL, Rand D, van den Berg H, Thornton S, Hodgkin M, Davey J, Ladds G: Dual positive and negative regulation of GPCR signaling by GTP hydrolysis. Cell Signal 2009, 21:1151-60.

38. Cotton M, Claing A: Src-mediated RGS16 tyrosine phosphorylation promotes RGS16 stability. Cell Signal 2009, 21:1045-53.

39. Krumins AM, Barker SA, Huang C, Sunahara RK, Yu K, Wilkie TM, Gold SJ, Mumby SM: Differentially Regulated Expression of Endogenous RGS4 and RGS7. J Biol Chem 2004, 279:2593-2599.

40. Hendriks-Balk MC, Hajji N, van Loenen PB, Michel MC, Peters SL, Alewijnse AE: Sphingosine-1-phosphate regulates RGS2 and RGS16 mRNA expression in vascular smooth muscle cells. Eur J Pharmacol 2009, 606:25-31.

41. De Vries L, Elenko E, McCaffery JM, Fischer T, Hubler L, McQuistan T, Watson N, Farquhar MG: RGS-GAIP, a GTPase-activating protein for Galphai heterotrimeric $\mathrm{G}$ proteins, is located on clathrin-coated vesicles. Mol Biol Cell 1998, 9:1123-34.

42. Ajit SK, Ramineni S, Edris W, Hunt RA, Hum WT, Hepler JR, Young KH: RGSZ1 interacts with protein kinase C interacting protein PKCl-1 and modulates mu opioid receptor signaling. Cell Signal 2007, 19:723-30.

43. Higuchi H, Yamashita T, Yoshikawa H, Tohyama M: PKA phosphorylates the p75 receptor and regulates its localization to lipid rafts. EMBO J 2003, 22:1790-800

44. Kawasaki Y, Zhang L, Cheng JK, Ji RR: Cytokine mechanisms of central sensitization: distinct and overlapping role of interleukin-1 beta, interleukin-6, and tumor necrosis factor-alpha in regulating synaptic and neuronal activity in the superficial spinal cord. $J$ Neurosci 2008, 28:5189-94.

45. Szabo-Fresnais N, Blondeau JP, Pomérance M: Activation of the cAMP pathway synergistically increases IL-1-induced IL- 6 gene expression in FRTL-5 thyroid cells: involvement of AP-1 transcription factors. Mol Cell Endocrinol 2008, 284:28-37.

46. Atkins CM, Oliva AA Jr, Alonso OF, Pearse DD, Bramlett HM, Dietrich WD: Modulation of the CAMP signaling pathway after traumatic brain injury. Exp Neurol 2007, 208:145-58.

47. Wu LJ, Steenland HW, Kim SS, Isiegas C, Abel T, Kaang BK, Zhuo M: Enhancement of presynaptic glutamate release and persistent inflammatory pain by increasing neuronal CAMP in the anterior cingulate cortex. Mol Pain 2008, 4:40-47.

doi:10.1186/1749-7221-5-18

Cite this article as: Li et al:: Functional cooperation of of IL-1 $\beta$ and RGS4 in the brachial plexus avulsion mediated brain reorganization. Journal of Brachial Plexus and Peripheral Nerve Injury 2010 5:18.

\section{Submit your next manuscript to BioMed Central and take full advantage of:}

- Convenient online submission

- Thorough peer review

- No space constraints or color figure charges

- Immediate publication on acceptance

- Inclusion in PubMed, CAS, Scopus and Google Scholar

- Research which is freely available for redistribution

Submit your manuscript at www.biomedcentral.com/submit
Biomed Central 